European journal of American studies

$10-2$ | 2015

Summer 2015, including Special Issue: (Re)visioning

America in the Graphic Novel

\title{
Skinner Sweet, American Vampire
}

James J. Donahue

\section{CpenEdition}

Journals

Electronic version

URL: https://journals.openedition.org/ejas/11019

DOI: $10.4000 /$ ejas. 11019

ISSN: 1991-9336

Publisher

European Association for American Studies

\section{Electronic reference}

James J. Donahue, "Skinner Sweet, American Vampire", European journal of American studies [Online],

10-2 | 2015, document 10, Online since 14 August 2015, connection on 21 September 2021. URL:

http://journals.openedition.org/ejas/11019; DOl: https://doi.org/10.4000/ejas.11019

This text was automatically generated on 21 September 2021.

Creative Commons License 


\title{
Skinner Sweet, American Vampire
}

\author{
James J. Donahue
}

1 The early years of the twenty-first century have borne witness to an increased fascination with vampires in American popular media. Following upon the heels of the enormously successful television show Buffy the Vampire Slayer (which aired from 1997 to 2003') as well as its less-successful spin-off Angel (which aired from 1999 to 2004), Americans have been inundated with vampires. From the immensely popular Twilight book and movie series to the popular novel (but less commercially successful movie adaptation) Abraham Lincoln, Vampire Hunter, vampires appear to have taken over American media and firmly re-established themselves as a fit vehicle for any number of stories, themes, or political issues.ii One recent manifestation of America's fascination with the undead bloodsuckers is Scott Snyder's and Rafael Albuquerque's current graphic novel series American Vampire. First published in 2010, the American Vampire series was immediately commercially popular (the first volume of the collected edition ${ }^{\text {iii }}$ debuted in 2010 on the New York Times Bestseller List for Graphic Books), and critically valued, having already won an Eisner Award.

2 One reason for the popularity and success of this series is the means by which it engages popular moments in American cultural history, and by doing so tapping into the various manifestations of The American Dream, particularly as understood through the lens of American Exceptionalism, which historian David M. Wrobel defines as "faith in the notion of uniqueness [that] clearly influenced the nation's culture and historical development" (ix). Following Wrobel's larger argument that "[t]he frontier became the key to America's exceptionalism" (vii), this article will first explore the means by which American Vampire engages the mythology of the American frontier. However, just as America adapted to technological advancements and cultural changes, so too does Snyder's and Albuquerque's mythic protagonist, Skinner Sweet, who comes to embody the shifting ground upon which American 
values are built. This article will show how Snyder and Albuquerque tap into and imaginatively employ America's foundational myth as well as America's more modern developments, demonstrating the changing landscape of American cultural history through America's first vampire, an undead witness to and symbol of the birth and continued growth of the nation.

з American Vampire follows the life of Skinner Sweet, a Wild West outlaw-turned-vampire whose adventures take place against the backdrop of paradigmatic moments in American history. As a character, Skinner Sweet first represents the two-sided coin of American identity as defined by the frontier mythology, and then develops into an undead embodiment of American cultural change. As the first vampire born on (and from) American soil, Skinner Sweet embodies the New World "rugged individual" often characterized as the stock American figure in contrast to the Old World, cultivated European. And, as we will see below, it is those "rugged individuals" who often initiate cultural change; essentially, Skinner Sweet represents the American frontiersman, whether those frontiers are physical, cultural, or metaphorical. However, as an autochthonous species born from (and thus tied to) the wild landscape, Skinner Sweet also embodies the "savage Indian" figure against whom the American frontiersmen defined their own civilized virtues. As such, Skinner Sweet is American twice over, both indigenous species (a version of a "native" American) as well as descendant of the European colonists who named this nation America and thus became Americans. By initially representing two sides of the coin that is early American identity, Skinner Sweet is later able to reinvent himself; as the American Dream redefines itself, so too does he. And by adapting their title character to the changing cultural landscape, Snyder and Albuquerque are able to use Skinner Sweet to comment on the development of the American Dream, highlighting the dark underbelly of the positive story America keeps telling itself about progress.

4 Although grounded in the mythos of the American frontier, the series opens in 1925, near Los Angeles, a time and place not immediately associated with the frontier. And as the series develops, the reader follows the adventures of Skinner Sweet, Pearl Jones (the first human Sweet turned into a vampire), and other characters through a series of major moments in American history, such as the early years of Hollywood's Golden Age, the Second World War, and the birth of rock 'n roll. In addition to giving readers an overview of American history as reimagined through the influence of vampires and those who hunt them (much as Abraham Lincoln, Vampire Hunter does for the Civil War, a time period not covered in American Vampire), Snyder and Albuquerque select moments in American history that reflect the values associated with American Exceptionalism. As such, American Vampire not only constructs the figure of an American vampire, but uses that figure to define what it means to be American.

1. 


\section{An American Vampire}

5 In many of their manifestations in American media, vampires are distinctly marked as European. For instance, both Buffy and Angel develop storylines tracing the vampires in southern California back to Europe. The vampires in Abraham Lincoln, Vampire Hunter are also Old World, European aristocracy. And of course, Dracula is Transylvanian. One reason for this is to mark the vampires as culturally other; being "undead," vampires are among but not assimilated into the American population. However, in American Vampire, the vampires are European not only to make them culturally other, but also to serve as a foil for the American vampire Skinner Sweet. One of the reasons why Skinner Sweet is an American vampire is because of his sharp difference from the European breeds.

6 1880; Sidewinder, Colorado. Skinner Sweet (so named for his sweet tooth) is a murderous bank robber, hunted by famed Pinkerton agent James Book as well as the wealthy bankers and railroad tycoons he steals from. Early in the series ("Bad Blood," vol. 1), the reader learns that Percy-one such wealthy banker and railroad tycoon-is a vampire who, after being gunned down by Skinner's gang, leaps out of his shallow grave, bites Skinner, bleeds into Skinner's eye from his own gunshot wound in the head, and leaves Skinner to die. A later story ("Deep Water," vol. 1) opens with Skinner Sweet in his grave, wide awake and bearing the tell-tale fangs of the vampire. At this point, he is just another vampire, no different from the one who inadvertently turned him. ${ }^{\text {iv }}$ While in his grave, Skinner eats a rat, again engaging in an act traditionally associated with vampires in American popular culture.v However, when the town flooded, something happened to Skinner Sweet: his coffin filled with water, and a close-up on his eyethat same eye Percy inadvertently bled into-revealed that he had changed. When grave robbers attempt to dig up his grave, Skinner breaks free, and a new breed of vampire is born: "Percy didn't realize that Skinner Sweet was something entirely new. Water wouldn't hold him; sunlight wouldn't burn him but starving in the dark, he was too weak to escape" ("Deep Water," vol. 1).

7 As the story develops over the next four volumes, the reader learns that Skinner Sweet possesses a different set of strengths and weaknesses from the breed of vampires who turned him; similarly, those vampires that Sweet turns possess his new strengths and weaknesses, thus developing a new breed. Explicitly invoking American Exceptionalism, Sweet will later tell Pearl (his first vampire) that their new powers are "ev-o-lution. And you, and me? We're it." And later: "Just picture it in automotive terms, Bloch and his kind, they're like... old, broken-down European clunkers, okay? But you and me, Dolly? We're like shiny new 1926 Fords. Top of the line, just rolled out onto the showroom floor" ("Morning Star," vol. 1). The American vampire is the new model, the advanced machine, the product of American industrial 
superiority. And while it is not (or perhaps not yet) revealed why Sweet and his progeny differ from the older breed, it's important to note that they do, and that the difference is clearly based on Sweet and his victims being American. The reader is told that "water wouldn't hold him," and so one can assume that somehow the water played a part in his transformation. ${ }^{\text {vi }}$ I would posit that, although not well explained, the reader is meant to understand that Skinner Sweet is somehow "baptized" into this new breed of vampire as a result of being buried in the American soil and washed by American waters. As such, Skinner Sweet is made into an American vampire not unlike how, according to Frederick Jackson Turner, the European became American: "The wilderness masters the colonist. It finds him a European in dress, industries, tools, modes of travel and thought.... In short, at the frontier the environment is at first too strong for the man.... The fact is, that here is a new product that is American" (Turner 4). Just as the European frontiersman became an American through contact with the American frontier, so too does Skinner Sweet become an American vampire through his more literal contact with the American landscape.

8 And it is for this reason that it's important that Snyder, et. al. begin their series in the 1880s as opposed to any other moment in American history. The Old West of the 1880s is a perfect chronotope (to borrow language from Mikhail Bakhtin) in that it represents the American frontier (even though, as Turner and others make clear, the frontier line followed European colonization westward across the North American continent). And Skinner Sweet, albeit in a perverted way, embodies the rugged American individual that Turner indicates by means of describing the environment that gave birth to him: "each frontier did indeed furnish a new field of opportunity, a gate of escape from the bondage of the past; and freshness, and confidence, and scorn of older society, impatience of its restraints and ideas, and indifference to its lessons" (38). Stories such as "Blood Vengeance" (vol. 1) "Strange Frontier" (vol. 3) and "Ghost War" (vol. 3) demonstrate Skinner Sweet's attempts at escaping the bonds of the past (here defined as the rules of the older, European breed which does indeed "scorn" him), as well as his impatience (remember, too, he was a bank-robber), and his indifference to the lessons learned from the older society (against the better judgment of the European vampires, he recklessly refuses to hide in the shadows; just as one of his new powers is an ability to function in daylight, he seems interested in bringing his existence out of the shadows and into the light of day, quite literallyvii).

9 However, as much as he is an American vampire based on his sharp distinction from the European vampires-that is, "American" here defined as "non-European"-Skinner Sweet is also American due to another opposition, that between the "civilized" American frontiersman and the "savage" Native American. Although one way to read Skinner's rebirth is in terms of the frontier rhetoric provided by Frederick Jackson Turner, he can just as easily be read as the autochthonous "native"-or indigenous-American whose existence is tied to the 
wilderness. To give but one of many examples, we might turn to Richard Slotkin's reading of Mary Rowlandson's captivity narrative, where he notes that "[h]er resistance to adopting the Indians' ways has prevented her captivity from becoming a complete initiation into the American wilderness" (112). The underlying assumption here is that the more one engages in the behavior of the Indians, the more one becomes a part of the wilderness; the indigenous people are inextricably connected to the land. And like the native land, the native inhabitants are wild and must be conquered. viii

${ }_{10}$ As Slotkin demonstrates, Native Americans have long been characterized as savage, noting how they "embody all evil" in several Puritan-era texts (89). Of course, vampires can also be said to "embody all evil," and even traditionally share with Native Americans such characterizations as hyper-sexuality (this is especially the case in renditions of Dracula), though this is not necessarily the case with Skinner Sweet. However, Slotkin does quote at length some Puritan-era texts describing Native American cannibalism, and here we see a connection to the vampire, a being who feeds on humans to survive. William Bradford, for instance, reported that "the savage people... delight to torment men in the most bloody manner that may be; flaying some alive with the shells of fishes, cutting off the members and joints of others by piecemeal and broiling on the coals, eat[ing] the collops of their flesh in their sight whilst they live" (qtd. in Slotkin 38). This description of the Native American parallels the characterization of Skinner Sweet as violent, savage cannibal. For instance, in his first human attack, Sweet is drawn nearly full-page, and his mouthespecially his teeth-is grotesquely exaggerated. (This will become true for every representation of the American vampires; their mouths and teeth are larger, more dangerous, and thus more savage than those of their European counterparts.) Sweet also asks of his victim, "Hello, motherfucker! GOT ANY CANDY?” One page later, after feeding upon two victims, Sweet again states his desire for candy, and the narrator notes that "the time of the American Vampire has come" ("Deep Water," vol. 1). Although it has been established that Skinner Sweet has a sweet tooth, I would like to suggest that two references to candy this close in the text serve to connect his sweet tooth to his new hunger; in other words, people are his new candy, thus emphasizing the cannibalistic aspect of the vampire's hunger.ix

${ }_{11}$ Perhaps in an attempt to more clearly identify American vampires with Native Americans, a later story arc introduces Mimiteh, a Native American vampire worshipped as a goddess by the Apaches. Like Skinner Sweet, Mimiteh was turned by European vampires and, just as importantly, her breed of vampirism had mutated (in her case, granting her immortality without feeding). Also like Skinner Sweet, Mimiteh is connected to the earth. First, she is hired by a party of European explorers to help them find passage through the wilderness (not unlike Sacagawea). She is then tied to the landscape visually in the graphic novel; as she narrates her backstory the reader is presented with full- 
page scenes of the wilderness. The suggestion is that Mimiteh is inextricably tied to this land. Later, in an ironic twist, Mimiteh will be trapped in a cave, literally becoming part of the landscape while serving as a war goddess for the Apaches. Then, near the end of the story arc, Mimiteh is asked to attack the American soldiers facing the Apaches; specifically, she is commanded to "Eat them!," to which she replies, "Eat them... Yessss... let us eat...." ("The Beast in the Cave," vol. 4). Here then we see in Mimiteh a figure where the Native American-ascannibal meets the American vampire-as-cannibal, now a larger than life mythological figure whose purpose is the savage destruction of civilization, here represented by the American military whose tailored and regimented uniforms contrast sharply with the disordered and haphazard clothing of the Apaches.

12 "The Beast in the Cave" fits within the larger narrative arc by also giving the reader backstory on Skinner Sweet. Set in the New Mexico Territory in 1871, this story follows a younger Sweet and his stepbrother Jim Book, the lawman who will later devote his career to hunting down Sweet. Before becoming an outlaw, Sweet (with Book) serves in the United States Infantry; however, his actions-disobeying orders, running into battle with guns blazing, and killing his superior officer to secure a promotion-are certainly in keeping with his later activities as an outlaw as well as a vampire. (They also allude to a dark interpretation of Turner's characterization of the rugged frontiersman.) Although Sweet pays a relatively minor role in this story arc, his presence does connect him to Mimiteh-now revealed as the first "American vampire"-and allows the reader to more clearly identify Sweet as a manifestation of the savage, cannibal Native American. This connection is emphasized on several pages, such as the paralleling of Sweet's murder of a fellow Infantry officer with Mimiteh's murdering of an Apache. In this facing-page parallel narrative, the two pages are divided into three panels: in the top panel, Sweet and Mimiteh attack their targets; in the middle panel, they address their victims; in the third panel, they flash their teeth in anticipation of consumption (Mimiteh bites into her victim while Sweet, not yet a vampire, bites into a candy cane). Visually, this narrative presents Sweet's actions as a mirroring of Mimiteh's actions; and knowing Sweet's future, the reader easily now identifies Sweet as an American soldier who has "gone Native." ${ }^{\prime}$

${ }_{13}$ Skinner Sweet, the American vampire, is thus constructed as two sides of the coin that is American identity as it was first formulated by the frontier mythology: the American is the non-European, the young upstart who breaks his bonds with his European past and constructs his identity on the new continent; however, the American is also the indigenous inhabitant, the Native American, the savage beast whose identity is tied to the savage wilderness. As such, Skinner Sweet as American vampire is a vehicle for the complicated cultural inheritance of the American frontier as it has come to serve as the basis for American Exceptionalism. However, just as American culture does not 
cease here, Snyder, et. al. do not end their explorations of American identity there. As noted above, this series sets many of its stories during paradigmatic moments in American history, exploring the actions of the American vampire against the backdrop of American cultural history. By selecting those specific moments, Snyder, et. al. are constructing a particular narrative and, as a result, emphasizing a particular definition of what it means to be American. Further, by carefully articulating two possibilities for understanding how Skinner Sweet can initially be read as "American," Snyder, et. al. subtly suggest that American identity is fluid rather than fixed. It is precisely this fluidity that allows Skinner Sweet to reinvent himself as the American Dream constantly transforms itself.

1.

\section{American (Vampire) History}

14As noted above, American Vampire explores major moments in American history, allowing for Skinner Sweet and (increasingly more frequently) his vampire progeny Pearl to engage in activities against a cultural backdrop that constantly redefines American identity. Beginning in the Old West of the 1880s (noting that "The Beast in the Cave" is set earlier), American Vampire emphasizes the development of American Exceptionalism-the belief that America is demonstrably better than other nations-that accompanied Manifest Destiny and persisted throughout the twentieth century. As David M. Wrobel has noted, "[t]he frontier became the key to America's exceptionalism" (vii); as such, we could read Skinner Sweet as living on both the actual as well as the metaphorical frontier, living on the cutting edge of American cultural development. Given Skinner Sweet's superiority compared to the European vampires, the reader is meant to read the American vampire as the superior species; even America's monsters are more exceptional, more savage. And in an ironic twist, while the American vampire is immune to some of the traditional methods used to kill vampires (wooden stake through the heart and sunlight), the American vampire has a weakness for gold. ${ }^{x i}$ This is doubly ironic. First, as a bank robber, Sweet would have been particularly keen on stealing gold; second, the gold rush (1848-1855) was one of the major factors contributing to both Manifest Destiny (the desire to move west) as well as American Exceptionalism (America is quite literally "worth" more). When Pearl apparently kills Sweet near the conclusion of "Ghost War," she does so by stabbing him with a gold knife. As such, the very material that he most coveted as an outlaw is what he must avoid as a vampire; perhaps American Vampire is also making a statement to its readers about the rampant, violent consumerism that only increased throughout the twentieth century.

${ }_{15}$ But Skinner Sweet is more than just a thief, and he survives beyond the Old West of the 1880s. The very first story in American Vampire ("Big Break," vol 1.) is set in 1925, thirty miles east of Los Angeles. Pearl Jones and her friend Hattie are aspiring actresses who catch the 
eye of the man we later learn is Skinner Sweet. Pearl, seduced by Hollywood, is taken by movie mogul B.D. Bloch to a party where she is given over to gang of vampires to be savagely attacked and nearly drained of her blood. Mimicking the stereotypical "casting couch" scenario-whereby young actresses are lured into the porn industry with the promise of eventual mainstream acting work-Pearl is here victimized by a wealthy, gluttonous, and most importantly above-the-law party of men. Left for dead in the desert, Pearl is found by her friends but "saved"-that is, turned-by Sweet, who kisses her open eye, mirroring the scene where Sweet is turned by getting Percy's blood in his eye. However, although she shares his strengths and weaknesses, she is not the same kind of vampire as Skinner Sweet; specifically, she does not become an outlaw, she marries and attempts to settle down, and she works to support the Vassals of the Morning Star, an organization devoted to hunting vampires. That is to say, while she does possess the capacity for brutal savagery-a capacity she employs at times to save the lives of others or avenge those who have been wronged-she is heroic in her actions where Sweet is savage. I would posit that this split is based (in part) on her not being tied to the wilderness the way Sweet is; in short, while Pearl is an American vampire, Skinner Sweet remains the American vampire.

16What's important here for the developing narrative of American Exceptionalism is that Pearl is an aspiring actress who is working at the birth of the Golden Age of Hollywood (the late 1920s to the early 1960s). Hollywood's Golden Age is connected to the Old West by the 1925 release of two movies that engaged the frontier mythology and contributed to the development of American Exceptionalism: Go West, starring Buster Keaton, and The Gold Rush, starting Charlie Chaplin. xii In Go West, Keaton plays a man named Friendless who goes west to earn his fortune, proving himself at such tasks as bronco busting and cattle wrangling, eventually leading a herd of cattle through Los Angeles (thus demonstrating his success "out west"). In The Gold Rush, Chaplin as The Tramp travels to the Yukon Territory to participate in the Klondike Gold Rush, though by the end of the film he gives up prospecting. Both of these movies engage the frontier mythology in some way, showing two figures (played by two of the Golden Age's most iconic actors) traveling west because that's where the fortune is. This, of course, is what also would have attracted the attention of such outlaws as Skinner Sweet, even though American Vampire makes no direct connection to either movie. However, because the series is specifically set in 1925, I believe that the authors are nodding toward such movies, as well as the more general allusion to Hollywood's role (which will only increase over the years) in the production and distribution of works that define American values both at home and abroad. In making Pearl a participant in the "Hollywood scene," Snyder et. al. link the American vampire to the film industry, an industry that continues to employ vampires to address aspects of American culture. I would suggest that, if the Old West serves to demonstrate that the 
American vampire's identity is a fluid construction, the Golden Age of Hollywood serves to remind us that American identity is always in flux, and that America is constantly reinventing itself and projecting new identities.

${ }_{17}$ The next historical period that serves as backdrop for a multi-story arc in American Vampire is the Second World War; the six-part "Ghost War" takes place (largely) in Taipei in 1943. Henry Preston, Pearl's human husband, enlists in the army and is then later enlisted by the Vassals of the Morning Star to help hunt down a breed of vampire specific to Taipei. Employing patriotic rhetoric common during war, Preston is "offer[ed]... the chance to participate in the greatest fight in the history of mankind-the fight against evil" ("Ghost War," vol. 3). As such, the hunting of vampires is tied to the American war efforts in the Second World War, two military efforts (albeit one covert, employed to eliminate any vampire threats to the Allied troops) used to rid the world of humans-become-monsters (as the Nazis and Japanese were often grotesquely characterized ${ }^{\mathrm{xiv}}$ ) who seek the subjugation and destruction of those not like themselves. The Vassals, then, work undercover as part of the larger war effort, as a unit sent to Taipei (presumably a first step in what would later lead to the Taipei Air Raid in 1945, the largest air raid on Taipei, resulting in the death, wounding, or displacement of tens of thousands). And along for the ride-reminding readers of his time in the U.S. Infantry-is Skinner Sweet, the most dangerous vampire in America.

${ }_{18}$ Unfortunately for Skinner, the Old West outlaw turned Second World War hero, the Taipei vampire proves to be far more powerful than he expected. First facing them on his own-brazenly calling them out with "Come on, you pussies... come to daddy Sweet!" ("Ghost War," vol. 3)Skinner is seriously injured by another vampire for the first time, and rather easily. This breed is more monstrous than even the American vampire; they are bigger, stronger, more brutal, and can turn their victims with only a bite, causing "a sudden, complete devolution into a feral mindset." In short, what the soldiers find on Taipei is truly monstrous, requires total extermination and, at first glance, the U.S. Army is not up to the job. As they soon learn, the Japanese army is planning on bombing Allied forces with weapons created from the blood of the Taipei breed, a "Doomsday device"-not unlike the atomic bombs that will later be dropped on Hiroshima and Nagasaki-designed to eliminate the enemy; by stopping the Taipei vampires, then, the U.S. Army (with the help of the Vassals of the Morning Star and Skinner Sweet) can help turn the tide of the whole war. And as one might suspect, despite being outnumbered, overpowered, and weakened, the small band of tough, resourceful Americans find a way to escape their captivity and destroy both the Doomsday weapon and the monstrous vampires; American Exceptionalism at work again, now on an international scale, due in large part to the superiority of the American vampire who, while physically weaker than the Taipei vampire, possesses enough of his wits (enough of his humanity) to prevail. The 
Americans, in other words, are no mere brutes, even the vampires. Like the frontiersmen of old, the American soldiers survive on the savage landscape by virtue of their inherent American superiority.

19 In the last chapter of "Ghost War," Pearl Jones and Skinner Sweet engage in an epic battle, spanning 7 pages (the longest and most developed fight of Skinner's life). Pearl here appears as more fearsome a foe than even the Taipei vampires. In fact, Pearl succeeds in besting Skinner, something the Taipei vampires, the European vampires, and the Vassals of the Morning Star have been unable to do. Reading this fight in light of the developing narrative of American Exceptionalism, it takes an American (vampire) to defeat an American (vampire). Although Skinner Sweet has been identified as the paradigmatic American vampire, by the end of the third volume his importance as the focal point for the developing narrative of American cultural values wanes; in other words, by the end of the third volume it would appear that the series is expanding the cast of characters to reflect America's expanding cultural developments. However, although he is no longer central, Skinner Sweet does appear in multiple stories in volume 4, largely in backstory (like "The Beast in the Cave") or flashbacks (as we see in "Death Race"). As such, Skinner helps tie the stories in volume 4 -stories featuring other American vampires-into the narrative of American Exceptionalism that has been developed in the first three volumes.

20 The 4-part story "Death Race" is set in Glendale, CA in 1954, right in the middle of the "Rock 'n Roll Revolution" sweeping the nation, and follows the adventures of Travis Kidd, independent vampire hunter. Sought after by both the Vassals of the Morning Star (who wish to recruit such a promising young talent ${ }^{\mathrm{xv}}$ ) as well as the vampires who would rather hunt than be hunted, Travis is the very embodiment of the 1950s rebel popularized by such movies as the 1955 classic Rebel Without a Cause, only he has a cause. In leather jacket, dark sunglasses, and sporting an Elvis Presley-inspired pompadour, Travis immediately presents himself as the rugged individual, breaking social convention, not unlike either the pioneers or the vampires who came before him. In fact, given his "bad boy" persona, his reckless driving (a common set piece from 1950s-era movies that is used as the opening sequence of "Death Race"), and the skull ring he gives his girl, many readers may at first read him as the vampire of the story, especially when he asks Piper to "neck." However, it quickly becomes clear that he's only using the girl to get at the vampires who have enslaved her; Travis Kidd, in other words, is the agent of freedom, there to "set you free, kid... free from these goddam bloodsuckers!" ("Death Race," vol. 4). Of course, it's not just his presentation-both as "bad boy" and as stereotypical American (true to his historical period)-or even the hints of darkness that allows the reader to first read Travis as a vampire (although both would be sufficient). Added to these markers is also the reader's expectation with respect to the developing narrative of the American vampire. In other words, having watched Skinner Sweet play 
the part of the rugged individual, the outlaw, the "bad boy," the reader is primed to see all such characters as potential vampires. And given the increasing number of American vampires, this may be intentional.

${ }_{21}$ However, Travis is a brutal vampire hunter-he puts in wooden dentures after his fights because "I like to bite them back" as he tells Piper-searching for Skinner Sweet, the vampire who killed his parents and caused him to be committed to the La Jolla Sanatorium (where he was treated with "electro-convulsive therapy" when nobody believed his story about vampires). And at the opening of the second part of "Death Race," Travis has found him. Their ensuing battle is important for three reasons. First, it demonstrates that Skinner Sweet did not die after fighting Pearl in Taipei, despite his wounds, Pearl's (apparent) killing blow with a gold dagger, and the subsequent bombing of the island. Second, Travis's use of a gold dagger suggests that knowledge of the American vampire's weakness has spread beyond the vampires and the Vassals. Third, and most importantly for the developing cultural narrative of American Vampire, Skinner Sweet is no longer the simultaneous embodiment and perversion of American values he has been to this point. Skinner Sweet seems to have been divested of all his positive cultural values; although he was instrumental in the U.S. Army's covert operations in Taipei, by turning on the soldiers at the end he effectively cut his ties with any lingering hopes of patriotism. In essence, by turning on those troops at the end, Skinner was cutting all his symbolic ties with America. Or, as he will later tell Travis, "In real life... the monster always wins in the end" ("Death Race," vol. 4). Skinner Sweet is no longer an embodiment of mythic frontier values, nor is he the two-sided coin of American cultural values identified above; now he is only a monster.

22 Taking up the mantle of American cultural identity is Travis Kidd. The transfer of values-the place in the narrative where Travis Kidd comes to represent what Skinner Sweet has for the previous three volumes-takes place during a break from their fighting where Travis reminds Skinner who he is, and why he holds a grudge. After Skinner notes that Travis's blood "[r]eminds me of the west," we learn that Travis spiked his own blood with gold dust (from his home in Las Vegas), just in case Skinner got the better of him and bit him. Explaining the murder of Travis's parents, Skinner notes that "I was never one for rules," to which Travis-in the last panel on the pagereplies, "Me neither" ("Death Race," vol. 4). And in perhaps the oddest twist of the series to date, their battle is interrupted by the Vassals, who reveal that Skinner Sweet has been working for them (but it is not revealed in what capacity), and Travis drives off to face his final battle against some two dozen members of the coven he was hunting earlier. However, where Skinner Sweet is carried away by the Vassals, weakened from his wounds, Travis very energetically pursues the coven. Skinner appears defeated, and at the very least under the orders of an organization previously devoted to killing him; Skinner Sweet has gone from rugged individual, flouting authority at every turn, to the 
subordinate of an administration that he loathes. The role of violent hunter, rugged individual, embodiment of the fearlessness associated with American Exceptionalism is now Travis Kidd, born of the frontier but now the paradigmatic rock 'n roll rebel. The last the reader sees of him, Travis is bursting through a door to attack some twenty vampires lying in wait, wearing his wooden dentures, guns blazing (like the outlaw Skinner once was) and shouting, "Let's rock and roll!" ("Death Race," vol. 4). Wearing his dentures at the start of the fight perhaps suggests that Travis is now, at least for the moment, the "American vampire," the rebel-with-a-cause and embodiment of the new America.

1. Conclusion

${ }_{23}$ By the end of the fourth volume of the continuing series American Vampire, Snyder, et. al. have begun to explore a variety of paradigmatic moments in the development of American Exceptionalism. Skinner Sweet, once the embodiment of the American cultural values by virtue of being both the frontiersman who broke the chains that his European forefathers wish to shackle him with and the savage autochthonous native born from the American soil, has now taken on a different role, one which will no doubt be explored in the volumes to come. And although it would appear that Travis Kidd-the figure I argue is the new recipient of the conflicting values Skinner once embodied-dies in his last action, the reader knows that mythic figures (such as Skinner once was) are very tough to kill, no matter the odds. Exceptional Americans will spring up from the soil with every new generation. However, regardless of whatever Travis's fate may be, the larger point is that the values Skinner Sweet initially embodied will live on in American culture in some form; the mantle will be passed on, but it will not be lost. As America continues to develop, so too will American vampires spring up to embody American values. American Vampire has tapped into and creatively rewritten America's most enduring mythology-the mythology of the American west-and traced its influence through paradigmatic moments of American history, moments that have been used to justify American Exceptionalism. And by telling that history through the adventures of a brutal yet charismatic monster who embodies the fluid nature of American cultural values, Snyder, et. al. allow for creative commentary on some of the most important moments in American history.

${ }_{24}$ The final story in volume 4- "The Nocturnes"-tells the story of Calvin Poole, operative of the Vassals of the Morning Star and, like Skinner Sweet, an American vampire. xvi Working in Midway, Alabama in 1954, Calvin hunts previously undocumented breeds of vampire. More importantly, however, he is also an African American who witnessesand counters-examples of racism perpetrated against African Americans: Calvin survives attacks from a gang of young thugs and, later, a group of older veterans, both of which clearly desire his death because he is black; one of the veterans laments that, "No one would 
have touched you until the fair was over. Of course, after the fair, we were going to kill you all like the trash you are.... So we were hoping to at least hear you sing, first" ("The Nocturnes," vol. 4). The old white men in charge, in other words, were eager to have "The Nocturnes" (a group of African American singers) perform, denoting a long-standing racial tension in America whereby African Americans are accepted, but only on limited terms as performers. Although this story arc does not develop this tension in detail, its inclusion in the volume suggests that American Vampire will continue to address major moments in American cultural history. Further, it suggests that the definition of "American" will continue to change (as well as expand to include people of different cultural heritages) and that the American vampire will continually develop as the embodiment of the tensions that define "America" in ways well worth following in later volumes of this series.

\section{BIBLIOGRAPHY}

De Crevecoeur, J. Hector St. John. Letter from an American Farmer and Sketches of EighteenthCentury America. New York: Penguin Books, 1981. Print.

Snyder, Scott and Steven King, writers. Art by Rafael Albuquerque. American Vampire, vol. 1. New York: DC Comics, 2010. Print.

Snyder, Scott. Art by Rafael Albuquerque. American Vampire, vol. 3. New York: DC Comics, 2012. Print.

Snyder, Scott. Art by Rafael Albuquerque. American Vampire, vol. 4. New York: DC Comics, 2012. Print.

Slotkin, Richard. Regeneration through Violence: The Mythology of the American Frontier, 1600-1860. Norman: U of Oklahoma P, 1973. Print.

Turner, Frederick Jackson. "The Significance of the Frontier in American History.” The Frontier in American History. New York: Dover Publications, 1996. 1-38. Print.

Wrobel, David M. The End of American Exceptionalism: Frontier Anxiety from the old West to the New Deal. Lawrence, KS: UP of Kansas, 1993. Print.

\section{NOTES}

i. The popularity of this television show (itself an adaptation of the 1992 movie Buffy the Vampire Slayer) can be witnessed in the enormous number of novels, comics, and video games that have been produced since the show went off the air. Many of these texts continue the timeline and expand the "Buffy-verse." And this is to say nothing of the countless fan-composed texts in print and online media. 
ii. Seth Grahame-Smith's brilliant historical revisionism in Abraham Lincoln, Vampire Hunterturning chattel slavery into a means to sustain a plentiful food source for vampiresdemonstrates the use to which vampires can be put in rethinking paradigmatic moments in American history, to which I will turn later in this essay.

iii. All references in the following essay will be made to the collected editions published in hardcover by Vertigo, as part of DC Comics. As the volumes contain no pagination, references will be made to story title and volume number.

iv. Traditionally, vampires "turn" their victims by first biting them, then having the victims drink their blood. In this case, Percy's blood was "ingested" by means of the eye socket.

v. For instance, Angel often fed on rats during his early years after getting his soul back (refusing to eat people anymore).

vi. This is not the only case in American popular culture where water would play a role in changing a vampire. In the 2009 movie Daybreakers, a former vampire known as Elvis (clearly a reference to American popular culture) is turned back into a human after a brief exposure to sunlight followed by being thrown into a lake.

vii. Blade, hero of the Blade trilogy of movies (Blade [1998], Blade II [2002], and Blade: Trinity [2004]), possessed the same power and was known among the traditional vampires-themselves part of an older European breed-as the "Daywalker."

viii. Even when written about positively, the Native American is still connected to the wilderness. See, for example, de Crevecoeur's comment about the tribesman who "mimicked the owls so exactly that a large one perched on a high tree over our fire" (92). Even in his long passages admiring the Native Americans (particularly compared to the white woodsmen; 71-73), he ties the indigenous people to the wilderness they inhabit. I choose this passage, in part, because it comes from de Crevecoeur's famous "What is an American?" letter.

ix. Mastication-as-violence appears elsewhere in American Vampire as well. In "Curtain Call" (vol. 1), Pearl kills her friend Hattie by shoving a star (the kind affixed to the doors of actors) in her mouth, telling her, "You want your star so bad Hattie? Eat it!"

x. This phrase-interchangeable with "gone savage"-is a not-uncommon way of characterizing Americans who have adopted Native customs. See, for instance, the movie adaptation of Dances with Wolves, when the United States soldiers take Lieutenant Dunbar/Dances with Wolves captive.

xi. American vampires also appear to weaken during moonless nights, though no explanation has been offered as to why.

xii. The Gold Rush was re-released in theaters in 1942, and released on DVD in 2003.

xiii. For instance, one could read Daybreakers as an argument against rampant American consumerism.

xiv. The next story arc, "Survival of the Fittest" (vol. 3), explores vampires in Nazi Germany, and battles against a "master race" of vampires, "The oldest, most powerful vampires in the world." Skinner Sweet, however, is not part of this story arc.

$\mathbf{x v}$. The reader learns that the Vassals of the Morning Star have been recruiting him since his childhood, and precipitated his escape from the La Jolla Sanatorium where he was committed after his parents' death.

xvi. Calvin was turned at the end of "Ghost War" (vol. 3), where a vial containing Pearl's blood broke and entered his bloodstream. Calvin was part of the covert operation in Taipei, serving both the U.S. Army and the Vassals of the Morning Star. 


\section{ABSTRACTS}

In their series American Vampire, Scott Snyder and Rafael Albuquerque create a new breed of vampire, one specific to America. In the full-length collections of their current series, Snyder and Albuquerque explore issues of American identity through the improbable birth and activities of this new breed and those who encounter it. Reborn as a vampire during the American west of the 1880s, Skinner Sweet embodies an American identity defined by the myth of the west and the American Dream it gave birth to. As an outlaw both in the eyes of the law as well as in the eyes of the older, European clans, Skinner embodies the spirit of revolution against tradition that has become one of the cornerstones of American identity associated with American frontier of rugged individualism. Similarly, as the first vampire born in America (in a space generally acknowledged as the birthplace of the American mythology), the ruthless killer Skinner also embodies the savagery associated with the Native Americans; and, like members of other indigenous tribes, Skinner is hunted by white lawmen for his crimes against civilization. As such, Skinner is both the savage "native" American whose execution is sought by the "civilized" whites, as well as the brash American seeking his Emersonian independence from European tradition. In the subsequent storylines, Skinner Sweet finds himself at various iconic moments of American cultural history: Hollywood in the 1920s, Las Vegas in the 1930s, and the Second World War. By placing Skinner in these moments, Snyder and Albuquerque select a specific timeline by which to chart America's development.

\section{INDEX}

Keywords: America, American Exceptionalism, frontier, Indian, savage, west

Mots-clés: Buster Keaton, Calvin Poole, Charlie Chaplin, Hector St. Jean de Crevecoeur, Introduction, James Book, Mary Rowlandson, Pearl Jones, Percy, Richard Slotkin, Skinner Sweet, Travis Kidd

\section{AUTHOR}

JAMES J. DONAHUE

State University of New York, Potsdam 